\title{
EDITORIAL
}

\section{The past and future of the Journal of Public Finance and Public Choice}

\author{
Emma Galli,emma.galli@uniroma1.it \\ DiSSE, Sapienza - Università di Roma, Italy
}

Giampaolo Garzarelli,giampaolo.garzarelli@uniroma1.it

DiSSE, Sapienza - Università di Roma, Italy;

IPEG, SEBS, University of the Witwatersrand, Johannesburg, South Africa

To cite this article: Galli, E. and Garzarelli, G. (2018) Editorial: The past and future of the

Journal of Public Finance and Public Choice, Journal of Public Finance and Public Choice, vol 33, no 1, 3-4, DOI: 10.1332/251569118X15214749647958

We are very pleased to present the new editorial project for the Journal of Public Finance and Public Choice (JPFPC) with Bristol University Press, an innovative, not-for-profit publisher of world-class research in the social sciences.

JPFPC, founded in 1983 (and directed, owned and principally sponsored) by Professor Domenico da Empoli (1941-2016), was the first European public economics journal explicitly covering Public Choice. ${ }^{1}$ Giannini Editore in Naples was JPFPC's first publisher under the title Economia delle scelte pubbliche/Journal of Public Finance and Public Choice. In 1997 Gangemi Editore in Rome took over publishing responsibilities when Public Choice still continued to have a minority status in Italian academia. The journal then changed title to Journal of Public Finance and Public Choice/Economia delle scelte pubbliche. The last issue published by Gangemi was the 2014, Volume 32, single issue $1 / 3$ (actually published in 2016). We are very grateful for their excellent job. The current owner and copyright holder of the journal is 'Associazione Economia delle Scelte Pubbliche' (AESP), which exclusively licenses all publication rights to Bristol University Press. At present, JPFPC will be published twice per year, continuing the original volume numbering. Back issues will also be available.

Da Empoli came into contact with Public Choice during a visiting period in the US, first at the University of Illinois (1965), and then at the University of Chicago (1966). At that time Public Choice - namely, the subfield of public economics that methodologically treats public sector analysis no differently from market analysis (homo economicus, methodological individualism, and politics as exchange) - was picking up momentum in the US. Da Empoli's background until then had mostly been in the Italian tradition of Scienza delle finanze. The Scienza delle finanze is a unique approach to public economics. Developed in Italy, beginning approximately at the end of the 1880s, it always stressed the importance of law and politics when considering the study of the workings of the public sector. Moreover, in line with its Italian origin, it is an approach that always kept a non-idealistic stance to the body politic: politicians are, like everyone else, self-interested. This means that public decisions 
originate from political compromises within an institutional framework that must also be considered. Two implications immediately follow: comparative institutional analysis matters; the institutions of the public sector are not perfect, they can fail just as those of the private sector can fail.

Da Empoli's Scienza delle finanze background was particularly congenial for Public Choice, also because Scienza delle finanze is one of the three traditions that build up Public Choice (the others being Austrian subjectivism and Wicksell's approach to collective decision making). Therefore, da Empoli immediately was able to pick up the potential of then-emerging Public Choice, on both positive and normative grounds: Public Choice offered a rigorous analytical lens that Scienza delle finanze at that time still lacked.

The rest is history. Since its birth JPFPC has published many works of Italian and international scholars, including Nobel Prize winners (M Allais, JM Buchanan, RH Coase, G Stigler). Over more than thirty years, thanks to constant and serious work by the former Editor and Editorial Board, all committed to publishing high-quality, peer-reviewed papers, and to their openness to new ideas, JPFPC has acquired a very good scientific reputation.

\section{What about JPFPC's future?}

Our objective is to keep JPFPC a high-quality outlet for thought-provoking research. One change with the past is that we will aim to make the content of JPFPC more reflective of its title: that is, to advance knowledge in both public finance and public choice. We do not wish to favour one approach over the other. Rather, the attempt is to stimulate fruitful debate over different, rival positions. JPFPC therefore is an inclusive outlet.

In this sense, we also welcome behavioural, experimental and multidisciplinary approaches. Moreover, we encourage submissions from economics, as well as from cognate disciplines (geography, law, political science, sociology), that contribute to our understanding of the public economy and its broader constitutional, legal and political economy matrix. Theoretical and applied papers, including contributions on the history of economic thought, are welcome. When considering a contribution's added value, JPFPC will continue to value originality over formalism.

We live in an era when journal indexing, metrics and turnaround times are increasingly influencing, especially in economics, an author's 'where to submit' decision. JPFPC is already present in several databases, including Australian, EconLit, French, and MIAR. The objective is also to include JPFPC in other relevant databases, with the intention to obtain journal metrics. Furthermore, we are committed to a quick turnaround time.

We are very grateful to Bristol University Press for believing in the JPFPC, and for recognising JPFPC's uniqueness in the international landscape of public economics journals.

\section{Note}

1 On Domenico da Empoli, see Galli, E, Garzarelli, G,Villani, M, 2016, Domenico da Empoli, In Memoriam, International Tax Law Review (Single Issue), 9-15, and Galli, E, Garzarelli, G, 2017, Domenico da Empoli (1941-2016), Homo Oeconomicus: Journal of Behavioral and Institutional Economics 34, 2-3, 253-5 